\title{
Profitability and forward linkage analysis of poultry feed mill in Bangladesh
}

\author{
M. A. Haque ${ }^{*}$ M. Akteruzzaman, M. A. Hashem ${ }^{1}$ and S. Haque \\ Department of Agricultural Economics and ${ }^{1}$ Department of Animal Science, Bangladesh Agricultural University, \\ Mymensingh-2202, Bangladesh, *E-mail: azad_231_bau@yahoo.com
}

\begin{abstract}
The study aims to examine the profitability and forward linkage analysis of poultry feed covering Dhaka, Gazipur, Narsingdi, Kishoreganj and Mymensingh districts. In total 30 feed mills which categorized such as high, medium and low quality on the basis of feed conversion ratio along with 45 dealers; 15 sub-dealers and 120 farmers purposively. The primary data were collected during March 2013 to March 2014 by using survey schedule, KII and FGD. In addition, the secondary data were collected from different government documents. It is evident that the cost of feed was found Tk. 39295, Tk. 38643 and Tk. 37218 per MT (metric ton) respectively for high, medium and low quality feed mills. The gross returns were found Tk. 43160, Tk. 42330 and Tk. 40500 per MT and gross margin was Tk. 6486, Tk. 5957 and Tk. 5285 per MT respectively. The net returns were found Tk. 3865, Tk. 3687 and Tk. 3279.2 per MT respectively. It indicates that total gross return, gross margin and net return of high quality feed mill is higher than medium and low quality feed mill. It is also evident that about $60 \%$ of raw materials were purchased from Dinajpur, Rangpur, Rajshahi, Jamalpur and coastal areas namely Bagergerhat, Chittagong and Khulna where as 100 percent of feed additives were imported. The unavailability of raw materials was the major problems for feed mills operation which influenced feed price and quality. If these problems could be solved within a reasonable time, stakeholders' would be able to get more benefits and run business smoothly.
\end{abstract}

Keywords: Profitability, Poultry feed, Supply chain

\section{Introduction}

Livestock is playing an important role in the national economy by contributing significantly to agriculture and to the gross national product of Bangladesh. The agricultural sector contributes $12.57 \%$ in the GDP whereas livestock sub-sector contributes $2.15 \%$ in the GDP (BBS, 2014). Furthermore, it plays a pivotal role in the rural socioeconomic system as maximum households are directly involved in livestock. Total investment in poultry industry was Tk. 150 billion with an annual turnover of Tk. 200 to 250 billion (Chowdhury, 2013). About 6 million people are employed in this industry and the number of commercial poultry farms in Bangladesh were 114,000 in 2010; 98000 in 2011 and 75000 in 2012 (Chowdhury, 2013). This has created job opportunity for more than 6 million people. Poultry industry is one of the major among livestock sub sectors that committed to supply cheap sources of good quality nutritious animal protein to the nation. Poultry meat production was 30.21lactons and egg production 67542.80 lac in 2013/14 (BER, 2014). People in Bangladesh raise poultry mainly with a view to getting meat and egg to fulfill their daily consumption. Chicken meat is also highly acceptable by all the religion of people and cheap source of animal protein.

The poultry industry is crucial in the context of agricultural growth and improvement of diet for the people in Bangladesh. This industry is particularly important in the sense that it is a significant source of supply of protein and nutrition in a household's nutritional intake. Poultry is a common enterprise in rural Bangladesh. The poultry industry in Bangladesh is very important for the reduction of poverty and creation of employment opportunities. In the recent times, the demand for milk has increased by 6 percent and eggs by 5.2 percent. Fish and cattle production require a longer time. But poultry production is relatively faster and easier, if public and private sector initiatives go side by side.

Poultry feed mill industry as an agribusiness enterprise is comparatively new in Bangladesh. Total feed business, especially, the business of concentrates was controlled by some feed traders. Bangladesh is a feed deficit country. At present there are about 250 registered feed mills in our country (Uddin, 2014). These feed mills are not produced sufficient amounts of feed. Shortage of feed is major constraints to the development of poultry sector in Bangladesh. There is a general agreement that low poultry production in 
Bangladesh is mainly due to lack of feed staff. The major feed additives are: toxin binder, mold inhibitor, enzymes, synthetic amino acids and vitamins, feed premixes, vitamin-mineral premixes, trace minerals, organic acids, probiotics, salmonella killer, antibiotic for therapeutic use through feeds (antibiotic as growth promoter is strictly prohibited to use in the feed according to Feed Act 2010). Most of the feed additives have been imported by the Health companies and feed millers. Major Feed ingredients have been imported by the commercial feed millers. Though, due to the government's initiatives, supply situation of feed has improved slightly, but still supply is very much inadequate in relation to high increasing demand. The expansion of commercial feed industry in Bangladesh can possible to fulfill more than $80 \%$ of the total compound feed requirements. Considering the existing growth rate of poultry, cattle and aquaculture, the estimated annual compound feed requirement would be 10.60 million MT in 20202021.

By ensuring the supply of quality feed for livestock sub-sector, the feed mill industry is enhancing the whole economy significantly through its forward linkage effect. The feed mill industry improves the efficiency and digestibility of feed through scientific formulation and processing and helps efficient use of scarce feed resources. This industry also generates a number of employments in the processing plants and involves a number of people in feed distribution channels. This increases the importance of the industry day by day. Realizing the importance of this industry, the GOB is trying to make involved more private entrepreneurs here. This study is a modest effort undertaken to examine the cost effective supply chain of raw materials and supply of poultry feed.

The specific objectives are:

i) to investigate the backward and forward linkages of feed mills; and

ii) to examine the cost effective supply chain of poultry industry by estimating the marketing cost and margin of feed miller and market intermediaries.

The information may be helpful to the existing and potential entrepreneurs and market participants to improve the supply chain and decisions.

\section{Materials and Methods}

The study was mainly based on field survey in addition of some secondary information. Purposive sampling technique was used in selected 30 feed mills. It was categorized by high, medium and low quality feed mill on the basis of feed conversion ratio (FCR). 30 feed mills, 45 dealer, 15 sub-dealer and 120 farms were selected on the basis of quality (FCR) from Dhaka, Gazipur, Narsingdi, Kishoreganj and Mymensingh districts. FCR categorized on the basis of collected from firms level data from feed performance. Table 1 show that multi-stages stratified sampling technique was adopted in this study. The selected 30 feed mills categorized on the basis of feed conversion ratio (FCR) that is high quality feed mills (FCR; below 1.5 to 1.6), medium quality feed mills (FCR: 1.6 up to 1.7) and low quality feed mills (FCR: 1.7 up). The selected commercial farms were categorized by flock size small scale: < 1000 birds, medium scale: $1001-2000$ birds and large scale: above 2000 birds.

Table 1. Distribution of sampled feed mills and poultry farms

\begin{tabular}{l|cc|c|c|c}
\hline \multirow{2}{*}{$\begin{array}{l}\text { Quality of feed } \\
\text { mills (FCR basis) }\end{array}$} & $\begin{array}{c}\text { Number } \\
\text { of } \\
\text { feed mills }\end{array}$ & $\begin{array}{c}\text { Small scale } \\
(<1000 \text { birds })\end{array}$ & $\begin{array}{c}\text { Medium scale } \\
(1001-2000 \text { birds })\end{array}$ & $\begin{array}{c}\text { Large scale (Above } \\
\text { 2000 birds })\end{array}$ & $\begin{array}{l}\text { Total } \\
\text { farm }\end{array}$ \\
\hline High & 10 & 20 & 10 & 10 & 40 \\
Medium & 10 & 20 & 10 & 10 & 40 \\
Low & 10 & 20 & 10 & 10 & 40 \\
\hline Total & 30 & 60 & 30 & 30 & 120 \\
\hline
\end{tabular}


In conformity with the objectives of the study, a structured questionnaire developed for collecting relevant primary data from the poultry feed miller, dealer and sub-dealer and farmers. The present study covered approximately from March 2013 to march 2014 study period and data analyzed with a combination of tabular and statistical techniques. The formulas need for the calculation of profitability is discussed below:

\section{Gross return}

Gross return calculated by multiplying the total volume of output of an enterprise by the average price in the harvesting period (Dillon and Hardaker, 1993). The following equation will have used to estimate GR:

Where,

$$
\mathrm{GRi}=\sum_{\mathrm{i}=1}^{\mathrm{n}} \mathrm{QiPi}
$$

GRi= Gross return from i-th product; $\mathrm{Qi}=$ Quantity of the i-th product; and

$\mathrm{Pi}=$ Average price of the $\mathrm{i}$-th product; andi $=1,2,3 \ldots \ldots \ldots \ldots \ldots . \mathrm{n}$.

\section{Gross margin}

Gross margin calculated by the difference between gross return and total variable costs.

That is,

Where,

$$
\mathrm{GM}=\mathrm{GR}-\mathrm{TVC}
$$

$\mathrm{GM}=$ Gross margin; $\mathrm{GR}=$ Gross return; and $\mathrm{TVC}=$ Total variable cost.

\section{Net return}

Net return analysis considered fixed costs i.e., cost of land rent, interest on operating capital, etc. Net return calculated by deducting all costs (variable and fixed) from the gross return. To estimate the relative profitability of different agricultural enterprises, profit equation of the following algebraic form was used:

Where,

$$
\Pi=\sum_{i=1}^{n}\left(P_{Y_{i}} \cdot Y_{i}\right)-\sum_{i=1}^{n}\left(P_{X_{i}} \cdot X_{i}\right)-T F C
$$

$\Pi=$ Net return; $P_{Y_{i}}=$ Price per unit of the $i$-th produce; $Y_{i}=$ Quantity of the $i$-th produce; $P_{X_{i}}=$

Price per unit of the $i$-th inputs; $X_{i}=$ Quantity of the $i$-th inputs; TFC = Total fixed costs; and $i=1,2,3, \ldots . n$ (number of items).

\section{Marketing system}

An attempt was made to characterise the existing marketing systems of poultry and their products. The following steps were followed in characterising marketing systems of the poultry products.

\section{Marketing margin (MM):}

Gross margin $=$ sales price - purchase price

Net marketing margin (NMM):

Net margin = gross margin - marketing costs

Return on working capital (ROWC):

Return on working capital $=\frac{\text { Net margin }}{\text { Working capital }} \times 100$

Working capital $=$ purchase price + marketing costs 


\section{Results and Discussion}

\section{Backward and forward linkages}

Poultry feed mills provide an important linkage between feed grain producers and feed using farms. The collection of raw materials related to poultry feed production is backward linkage and feed distribution is forward linkage. Raw materials were collected from two sources-firstly from domestic source and secondly import from others countries. Rice bran and rice polish was mainly collected from the rice processing mills spread all over the country. But the major portion of domestic rice bran and polish were supplied from the Rajshahi and Rangpur divisions. Table 2 shows that $60 \%$ maize were collected from domestic sources like; Dinajpur, Rangpur, Rajshahi and Northan area of Bangladesh and 40\% maize were imported from India, USA, Bhutan and Brazil. 80\% of rice polish and rice bran collected from Dinajpur, Rangpur, Rajshahi and Jamalpur area a small portion of rice polish and rice bran was also imported from India and Thailand. $40 \%$ of full fat soybean and soybean meals were collected from Noakhali, Northern area and $60 \%$ of full fat soybean and soybean meals were imported from India, USA and Brazil. $80 \%$ of fish meal, fish fat, dried fish and poultry meat, poultry fat, dried poultry were mainly collected from coastal areas such as Bagerhat, Chittagong and Sundarban area of Bangladesh and 20\% from China, Brazil Vietnam and Indonesia. A small portion of coconut cake came from Bagerhat and Khulna districts of Bangladesh, but $80 \%$ of coconut cake and copra meal imported from Sri Lanka and India (Field survey, 2014).

Table 2. Sources of raw material of poultry feed

\begin{tabular}{|c|c|c|c|c|}
\hline \multirow[t]{2}{*}{ Items } & \multicolumn{2}{|l|}{ Domestic sources } & \multicolumn{2}{|l|}{ Imported } \\
\hline & Main districts & Percent & Main country & Percent \\
\hline Maize & $\begin{array}{l}\text { Dinajpur, Rangpur, Rajshahi and } \\
\text { Northan Area }\end{array}$ & 60.0 & $\begin{array}{l}\text { India, USA, Bhutan } \\
\text { and Brazil }\end{array}$ & 40.0 \\
\hline $\begin{array}{l}\text { Rice bran and rice } \\
\text { polish }\end{array}$ & $\begin{array}{l}\text { Dinajpur, Rangpur, Rajshahi and } \\
\text { Jamalpur Area }\end{array}$ & 80.0 & India, Thailand & 20.0 \\
\hline $\begin{array}{l}\text { Full fat soybean and } \\
\text { soybean meals }\end{array}$ & Noakhali, Luckpur, Northern area & 40.0 & India, USA, Brazil & 60.0 \\
\hline $\begin{array}{l}\text { Fish meal, fish fat, } \\
\text { dried fish }\end{array}$ & $\begin{array}{l}\text { Coastal areas such as Bagerhat, } \\
\text { Chittagong, Sundarban and Haor areas }\end{array}$ & 80.0 & $\begin{array}{l}\text { China, Brazil } \\
\text { Vietnam, Indonesia }\end{array}$ & 20.0 \\
\hline Coconut cake & Bagerhat and Khulna & 20.0 & Sri Lanka and India & 80.0 \\
\hline Protein concentrates & - & - & $\begin{array}{l}\text { Netherlands and some other } \\
\text { countries of Europe. }\end{array}$ & 100.0 \\
\hline $\begin{array}{l}\text { Vitamins and mineral } \\
\text { premixes, chemicals } \\
\text { and medicines }\end{array}$ & - & - & $\begin{array}{l}\text { America, Germany, China, } \\
\text { Vietnam and India }\end{array}$ & 100.0 \\
\hline Feed binders & - & - & $\begin{array}{l}\text { America, India, China and } \\
\text { Malaysia }\end{array}$ & 100.0 \\
\hline
\end{tabular}

The raw material collection channels, which were used commonly by the feed mills of Bangladesh, are illustrated in following Fig. 1. 


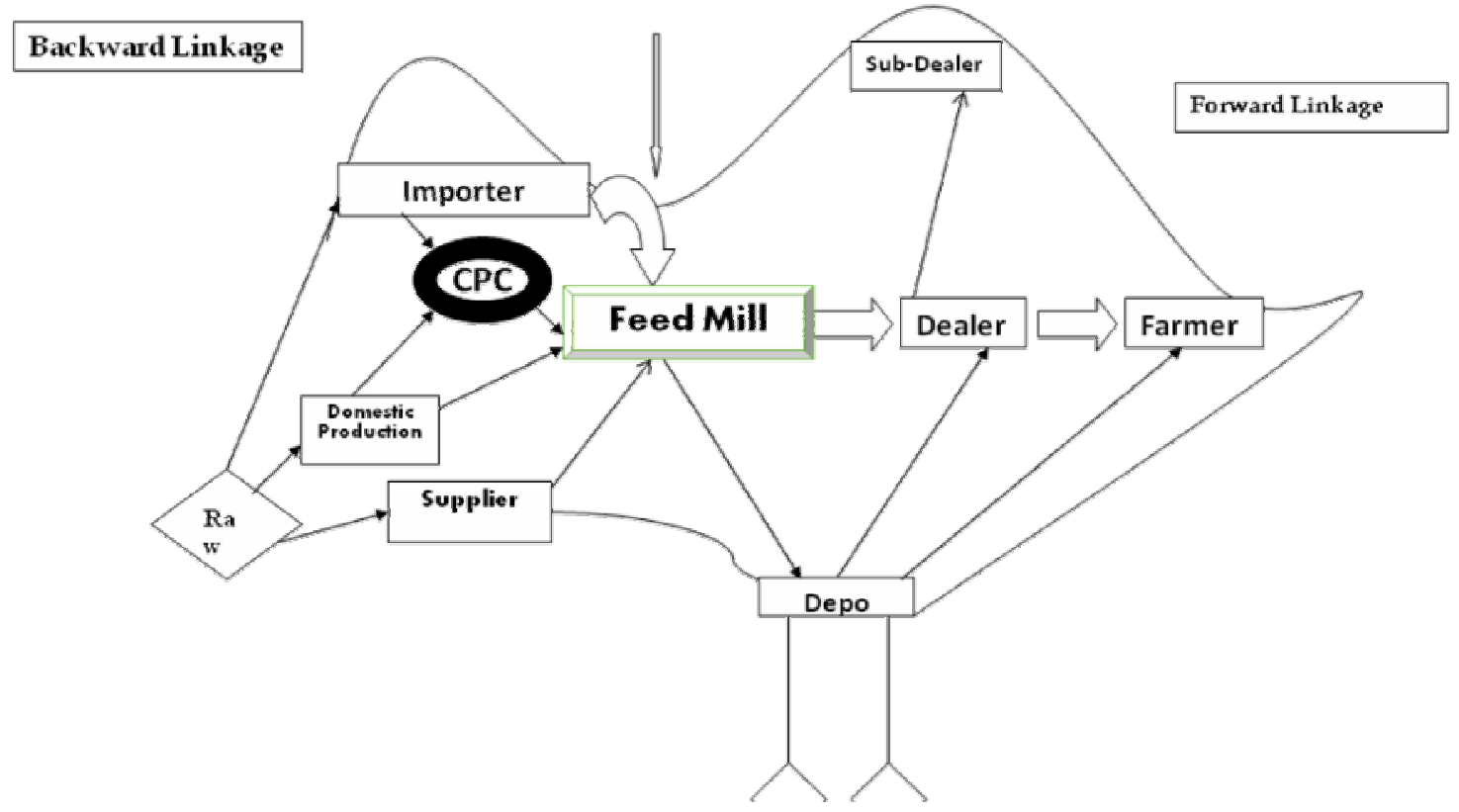

Fig. 1. Channels of backward and forward linkages of poultry feed in Bangladesh

\section{Poultry feed production steps}

In order to get prepared feed, the feed ingredients have to go through a long mechanical process. The whole process can be divided into seven stages which are as follows: Bagging is an important step in feed processing. For bagging the feed, bags made of polypropylene (PP) are used. Brand name, trademark of the producer, specification of feed, net weight, date of production and other necessary information are printed on the bags. Each bag generally contains $50 \mathrm{~kg}$ feed-which gives it an easy handling and well stacking characteristics. After preparing feed, different types of feeds are stored separately (Fig. 2).

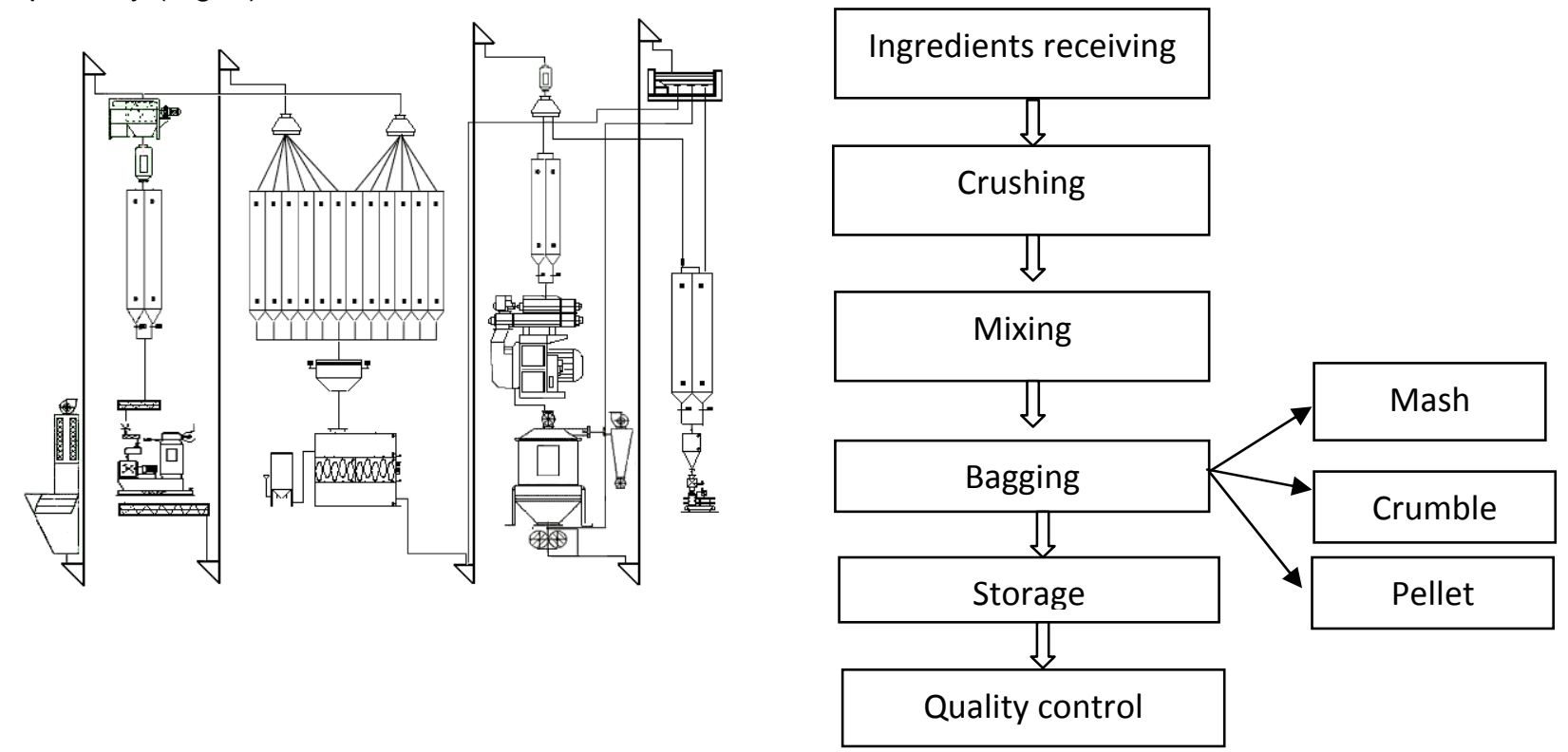

Fig. 2. Steps involved in poultry feeds production 


\section{Production cost of poultry feed mills}

The term cost generally refers to outlay funds for poultry feed mill. Cost items are classified into two major groups e.g., fixed cost and variable cost and these together equaled total cost. In the present study high quality poultry feed production cost was higher than medium and low quality of poultry feed. High quality poultry feed production cost was Tk. 39295 per metric ton $(39.29 \mathrm{Tk} . / \mathrm{kg})$ where medium and low quality of poultry feed production cost per metric ton was Tk.38643 (38.63 per kg) and Tk. 37218 (37.49 per kg) respectively (Table 3 ). All variable and fixed cost is decreasing with feed quality because of quality feed depends on the cost of different items of feed production posses.

In the study average gross return from high quality poultry feed production was higher than average medium and low quality of poultry feed. High quality poultry feed gross returns was Tk. 43160 per metric ton where Tk. 42330 and Tk. 40500 per metric ton respectively a average medium and low quality of poultry feed (Table 4).

Table 3. Production cost of different quality poultry feeds mills

\begin{tabular}{|c|c|c|c|}
\hline Item & $\begin{array}{l}\text { High quality } \\
\text { (Tk./MT) }\end{array}$ & $\begin{array}{l}\text { Medium quality } \\
\text { (Tk./MT) }\end{array}$ & $\begin{array}{l}\text { Low quality } \\
\text { (Tk./MT) }\end{array}$ \\
\hline \multicolumn{4}{|l|}{ A. Variable cost } \\
\hline Raw Material cost & 32203.9 & 32082 & 31389 \\
\hline Electricity cost & 450.41 & 440 & 400.7 \\
\hline Marketing cost & 3000 & 2888.3 & 2552.8 \\
\hline Maintenance cost & 120.33 & 100.88 & 110 \\
\hline Interest on working capital & 900.04 & 862.6 & 763 \\
\hline Total variable cost & 36674 & 36373 & 35215 \\
\hline \multicolumn{4}{|l|}{ B. Fixed cost } \\
\hline Land use cost & 320.73 & 290 & 250 \\
\hline Machinery, Tools \& Equipment cost & 820.24 & 739.33 & 687.8 \\
\hline Building ,Warehouse \& others cost & 400.53 & 350.7 & 300 \\
\hline Salary \& Wages cost & 1030.1 & 850 & 730 \\
\hline Electrification gas/generator cost & 20 & 10 & 10 \\
\hline Permanent labor cost & 30 & 30 & 28 \\
\hline Total fixed cost & 2621 & 2270.03 & 2005.8 \\
\hline Total $\operatorname{cost}(A+B)$ & 39295 & 38643 & 37218 \\
\hline
\end{tabular}

Table 4. Return from different poultry feed mills

\begin{tabular}{lccccc}
\hline Item & $\begin{array}{c}\text { Total quantity } \\
\text { (MT/Month) }\end{array}$ & $\begin{array}{c}\text { Sales price } \\
\text { Tk./kg }\end{array}$ & $\begin{array}{c}\text { Gross return } \\
\text { (Taka) }\end{array}$ & $\begin{array}{c}\text { Gross return } \\
\text { (Tk./MT) }\end{array}$ \\
\hline High quality feed & 11321 & 43.16 & 488614360 & 43160 \\
Medium quality feed & 6778 & 42.33 & 286912740 & 42330 \\
Low quality feed & 1743 & 40.5 & 70591500 & 40500 \\
\hline All average & 6614 & 42 & 282039533 & 41997 \\
\hline
\end{tabular}

Average gross margin, net return and BCR was Tk. 6058, Tk. 3438 and 1.1 per ton respectively for high quality poultry feed mill, Tk. 5957, Tk. 3687, 1.12 for average medium quality poultry feed mill and Tk. 5285, Tk.3282 and 1.10 for average low quality poultry feed (Table 5). In this study area high quality feed production per month was more than medium and low quality feed production because of high quality feed demand higher than medium and low quality feed. 
Table 5. Total return, gross margin, net return, BCR (undiscounted) for different poultry feed production

\begin{tabular}{l|c|c|c}
\hline \multirow{2}{*}{ Item } & $\begin{array}{c}\text { High } \\
\text { quality feed }\end{array}$ & $\begin{array}{c}\text { Medium quality } \\
\text { feed }\end{array}$ & $\begin{array}{c}\text { Low } \\
\text { quality feed }\end{array}$ \\
\cline { 2 - 4 } & Taka/MT & Taka/MT & Taka/MT \\
\hline A. Gross return (GR) & 43160 & 42330 & 40500 \\
B. Variable cost (VC) & 37102 & 36373 & 35215 \\
C. Fixed cost (FC) & 2620 & 2270 & 2003 \\
D. Total cost (TC)=(B+C) & 39722 & 38643 & 37218 \\
E. Gross margin (GM)=(A-B) & 6058 & 5957 & 5285 \\
F. Net return (NR)=( E-C) & 3438 & 3687 & 3282 \\
G. Benefit cost ratio(BCR= A/D) & 1.10 & 1.12 & 1.10 \\
H. Net return per taka investment (F/D) & 0.10 & 0.11 & 0.1 \\
\hline
\end{tabular}

Distribution channel plays a very important role in achieving marketing objectives of a company. By performing the work of transferring products from producers to consumers, a distribution channel overcomes the time, place and possession gaps that separate goods and services from those who need or want them. The feed mills under this category used slightly more complex channels to distribute their products. An outline of the distribution channels used by the privately owned feed mills is illustrated in Figure 1.

On the basis of Figure 1, the following channels of distribution can be identified;

Channel I: Feed mill $\rightarrow$ Sales Centre $\rightarrow$ Dealer $\rightarrow$ Poultry farm

Channel II: Feed mill $\rightarrow$ Dealer $\rightarrow$ Poultry farm

Channel III: Feed mill $\rightarrow$ Poultry farm

Channel IV: Feed mill $\rightarrow$ Dealer $\rightarrow$ Sub-dealer $\rightarrow$ Poultry farm

Channel V: Feed mill $\rightarrow$ Sales Centre $\rightarrow$ Dealer $\rightarrow$ Sub-dealer $\rightarrow$ Poultry farm

Among the above mentioned channels, channel-I and II were the most important channels and also used widely as the main channels. Table 6 shows that marketing margins of market actors. The marketing margin of high quality feed dealer and sub-dealer are higher than medium and low quality feed dealer and sub-dealer.

Table 6. Marketing margin of poultry feed miller, dealer and sub-dealer

\begin{tabular}{|c|c|c|c|c|c|c|c|}
\hline $\begin{array}{ll}\text { Level of } \\
\text { quality }\end{array}$ & Intermediaries & $\begin{array}{l}\text { Purchase } \\
\text { price/ } \\
\text { MT(Tk.) }\end{array}$ & $\begin{array}{l}\text { Sales } \\
\text { price/ } \\
\text { MT(Tk.) }\end{array}$ & $\begin{array}{c}\text { Gross Marketing } \\
\text { margin/ } \\
\text { MT(Tk.) }\end{array}$ & $\begin{array}{l}\text { Marketing } \\
\text { cost/ } \\
\text { MT(Tk.) }\end{array}$ & $\begin{array}{l}\text { Net marketing } \\
\text { margin/ } \\
\text { MT(Tk.) }\end{array}$ & $\begin{array}{l}\text { Return on } \\
\text { working } \\
\text { capital (\%) }\end{array}$ \\
\hline High & Miller & 39295 & 43160 & 3865 & 3000 & 865 & 8.07 \\
\hline \multirow[t]{2}{*}{ quality } & Dealer & 43160 & 44643 & 1483 & 566.85 & 916.15 & 2.10 \\
\hline & Sub-Dealer & 43360 & 44643 & 1283 & 348.94 & 934.06 & 2.13 \\
\hline Medium & Miller & 38643 & 42600 & 3957 & 2880 & 1077 & 9.66 \\
\hline \multirow{2}{*}{ quality } & Dealer & 42600 & 43756 & 1156 & 563.03 & 592.97 & 1.37 \\
\hline & Sub-Dealer & 42806 & 43756 & 950 & 331.95 & 618.05 & 1.43 \\
\hline \multirow[t]{3}{*}{ Low quality } & Miller & 37218 & 41010 & 3792 & 2550 & 1242 & 9.91 \\
\hline & Dealer & 41010 & 42050 & 1040 & 472.46 & 567.54 & 1.36 \\
\hline & Sub-Dealer & 40900 & 42050 & 1150 & 313.79 & 836.21 & 2.03 \\
\hline
\end{tabular}




\section{Conclusion}

The findings of the study of high quality feed are better than medium and low quality feed. The poultry feed production cost and gross margin, gross return and net return of high quality feed mills are higher than the medium and lower quality feed mills. The study concluded that the benefits from broiler production is depends on supplying the birds with the highest achievable quality of feed. The study also identified the unavailability of raw materials were the major problems for feed mills operation which influenced feed price of poultry feed and quality. The profitability of poultry feed production is quite satisfactory and have capability to attract interest of the entrepreneurs of Bangladesh. The trading of poultry feed is a profitable venture to the dealers and sub-dealers. Al well as Government has to take proper measure to increase the production of maize, wheat, soybean etc. throughout the country in order to reduce dependency on import.

\section{References}

Chowduary, S.D. 2013. Opportunities and Challenges Facing Commercial Poultry Production in Bangladesh Eighth International Poultry Show and Seminar, WPSA-BB, Dhaka, Bangladesh.

DLS. 2016. Brochure on Development and Activities. Department of Livestock Services, Dhaka, Bangladesh.

Dillon, J.L., Hardaker, J.B. 1993. Farm Management Research for Small Farmer Development, Food and Agriculture Organization of the United Nations, Rome.

Uddin, M.M. 2014. Animal Feed Resources and their Management in Bangladesh: Precedence on Assessment of Animal feeds and their characterization, FAO, Regional Office, Bankok, Thailand. 